\title{
Thermal Modernization Cost and the Potential Ecological Effect-Scenario Analysis for Thermal Modernization in Southern Poland
}

\author{
Rafał Blazy $^{1, *(D)}$, Jakub Błachut ${ }^{1}\left(\mathbb{D}\right.$, Agnieszka Ciepiela $^{1}\left(\mathbb{D}\right.$, Rita Labuz $^{1}$ (D) and Renata Papież $^{2}$ \\ 1 Faculty of Architecture, Cracow University of Technology, Warszawska Street 24, 31-155 Kraków, Poland; \\ jakub_blachut@o2.pl (J.B.); ak.ciepiela@gmail.com (A.C.); rita.labuz@pk.edu.pl (R.Ł.) \\ 2 Faculty of Economics, Finance and Law, Cracow University of Economics, Rakowicka Street 27, \\ 31-510 Kraków, Poland; renata.papiez@uek.krakow.pl \\ * Correspondence: r_j_blazy@wp.pl
}

check for

updates

Citation: Blazy, R.; Błachut, J.; Ciepiela, A.; Łabuz, R.; Papież, R. Thermal Modernization Cost and the Potential Ecological Effect-Scenario Analysis for Thermal Modernization in Southern Poland. Energies 2021, 14, 2033. https://doi.org/10.3390/ en14082033

Academic Editor: Dimitrios Katsaprakakis

Received: 26 February 2021

Accepted: 2 April 2021

Published: 7 April 2021

Publisher's Note: MDPI stays neutral with regard to jurisdictional claims in published maps and institutional affiliations.

Copyright: (c) 2021 by the authors. Licensee MDPI, Basel, Switzerland. This article is an open access article distributed under the terms and conditions of the Creative Commons Attribution (CC BY) license (https:/ / creativecommons.org/licenses/by/ $4.0 /)$.

\begin{abstract}
Air pollution is one of the important environmental problems in Poland. The main cause of its occurrence is emissions associated with individual heating of buildings. The reduction of the primary energy demand in a building is influenced by its proper thermal modernization, including in particular insulating. In view of the above, this article presents the results of studies on the possible environmental benefits of thermal modernization of single-family houses for the area of Southern Poland. The analysis was limited to determining the impact of measures to reduce air pollution emissions by insulating the building envelope of single-family houses. The research was conducted for two voivodeships: Ślaskie and Małopolskie. Its aim is to identify the financial costs and achievable ecological effects of the thermal modernization of single-family buildings. The geographical selection of the research area was based on the fact that it covers the most polluted region in Poland. This region is characterized by many features that influence poor air quality. Among these features, the most important are: diversified building structure, a diverse topography, and very high population density. To limit multiple variables, we have selected a scenario method that has already been used in similar research. Four scenarios were established to show the relationship between the value of emission reductions and the level of funding for thermal modernization. The analysis allows a comparison of the effectiveness of individual variants and the transposition of their results into the possibilities of action in the region. This research will help to supplement the knowledge of the impact of insulating building envelopes on reducing pollutant emissions by reducing the energy demand of a building. They also identify a possible link between the level of this reduction and the grant amount for thermal modernization. As a result, it was found that a high share of external funding-stimulating the tendency of the inhabitants of the analyzed voivodeships to effective thermal modernization, and thus reducing the buildings' energy consumption-has a significant impact on the improvement of air quality.
\end{abstract}

Keywords: thermal modernization; air pollution; ecological effect; single-family buildings; Śląskie voivodeship; Małopolskie voivodeship

\section{Introduction}

Poland is an infamous leader in terms of low air quality, which is one of the most polluted in Europe. According to the Reports of the European Environment Agency, Poland is one of the countries with very high exceedances of air quality standards, especially in its southern area [1,2].

According to the data collected by the National Center for Emissions Balancing and Management, solid fuel combustion in individual central heating furnaces and boilers - so-called low emissions-is responsible for half of the smog in Poland [3]. Industry, agriculture, and road transport are other significant emitters of pollutants $[4,5]$. One of 
the parameters of air quality assessment is the concentration of benzo(a)pyrene contained in it-a carcinogenic product of solid fuel combustion. Heat sources using solid fuels are responsible for over $80 \%$ of the emissions of this substance. Its highest concentrations and other polycyclic aromatic hydrocarbons occur mainly in the autumn-winter time in densely built-up areas where single-family buildings or apartments are heated with coal or wood [6,7].

Fortunately, the consciousness of decision-makers and the Polish society about the high harmfulness of polluted air is still growing [8]. In order to counteract of the problem aggravation, in 2018 the government "Clean Air" Program (hereinafter the Program) was launched. Financial subsidies from the State budget for initiatives focused on improving air quality are provided for by the Program [9]. The aim of the Program is to eliminate 3 million old-type domestic central heating installations-in the overwhelming number of installations, low-quality and energy-efficient solid fuels are burned [10,11]. To achieve the goal, funds in the amount of PLN 103 billion ( EUR 22.4 billion) have been declared, mainly for thermo-modernization of houses and replacement of boilers [12]. The duration of activities for the full achievement of the goal is planned for 10 years. However, despite the budgetary financial support, the thermal modernization process is progressing too slowly in relation to the Program schedule. During the two years of its operation, only 177,000 applications have been submitted and 146,000 subsidy agreements have been signed throughout the country [13].

The low level of financial resource allocation is a premise for undertaking research aimed at assessing the size of the potential environmental effect that could be achieved by the Program financing. We assume that the possibility of obtaining environmental benefits by increasing the effectiveness of the Program is achievable. Benefits, such as reduction of air pollutant emissions, can be achieved as a result of thermal modernization of single-family buildings-which consists of the thermal insulation installation of an external building partition - in Southern Poland, the most polluted area of Poland.

\section{Purpose, Methods, and Territorial Scope of the Research}

The aim of the research is an attempt to estimate the optimal financial cost of thermal modernization of single family houses, which would be acceptable for the inhabitants, and thus highly probable to be implemented in real life. Defining the aim in that way allows us to formulate a hypothesis: the acceptable cost of financing thermal modernization will impact to increasing the national "Clean Air" Program implementation tempo and consequently in achieving an ecological effect, which will be the air quality improvement in Poland.

Research and literature analysis focused mainly on examples of the area of Poland. This issue is also raised by foreign literature [14-17]. There are empirical studies on the impact of thermal modernization on the amount of pollutant emissions into the environment created by the heating process of buildings. These include comprehensive activities related to the replacement of heating sources, heating systems, etc. They focus especially on selected individual objects, e.g., sacred or multi-family development [18-20]. Analyses are also being carried out to determine the number of people willing to carry out the thermal modernization with the amount of its costs with possible funding [21]. However, the literature does not deal with the issues related to the impact of reducing the energy demand of a single-family building on particulate matter emissions, solely by insulating its building envelope. The topic which needs to be supplemented is also about the linking of the reducing pollutant emissions with the subsidy of thermal modernization, in particular for the Małopolskie and Śląskie voivodeships. In view of the above, this article supplements the knowledge on the ecological effects of thermal modernization processes in the field of building insulation. It also draws attention to improving the effectiveness of these measures through the financial support expected by single-family homeowners.

In order to achieve the assumed goal, a scenario analysis method was chosen which is widely used in various fields where future projection supporting decision making is 
required $[22,23]$. The usefulness of the scenario analysis method is determined by several features and it is not free from some weaknesses [24]. On the one hand, the method allows for avoiding the limitations resulting from the influence of certain dependent variables on the behavior of the studied entities, and on the other hand, it allows for testing tools in one study that would normally require long-term approaches to measuring dependent variables [25]. Moreover, the method has a high degree of utility. When it is correctly applied, it is highly useful in very different fields [26-28]. The studies adopted four scenarios, defining the relationship between the level of funding for thermal modernization and the number of people willing to undertake such an investment. Their assumptions were established in the same way as in the case of research conducted by M. Dzikuć and others [21]. Then, based on data from nationwide surveys, the number of buildings whose owners see the need to insulate the outer partitions and the average cost of such an investment for a representative size of the facility was determined. As a result, the potential cost of warming the indicated buildings in each province was calculated according to each scenario. In the analysis of the effect of insulating the building envelope on the reduction of air pollutant emissions, emission levels were compared for a noninsulated building $\left(\mathrm{EP}=180 \mathrm{kWh} /\left(\mathrm{m}^{2}\right.\right.$ year $)$ ) and insulated (after thermal modernization, $\mathrm{EP}=90 \mathrm{kWh} /\left(\mathrm{m}^{2}\right.$ year $\left.)\right)$. The results were then aggregated on a voivodeship scale. Based on the assumptions of the scenario analysis, the expected emission reduction values are defined in each variant depending on the level of the thermal modernization funding. On the basis of these, optimal options have been identified which could contribute to the greatest possible reduction of air pollutants.

The choice of the geographical area of the research was determined by the data showing the current level of air pollution in various regions of Poland. Polish Smog Alert (PSA) - based on its own analysis and National Environmental Monitoring data from 2019-has compiled a list of 15 towns in Poland with the highest air pollution rate. Small and medium-sized towns as well as villages in this group are predominant. This indicates that the problem of poor air quality does not only occur in large cities $[29,30]$ Over $50 \%$ of the towns from the PSA list are located in southern Poland -in the Ślaskie and Małopolskie voivodeships (Figure 1). These data clearly indicate that this is a crucial region of Poland-air quality improving in this area will have an importance throughout the country.

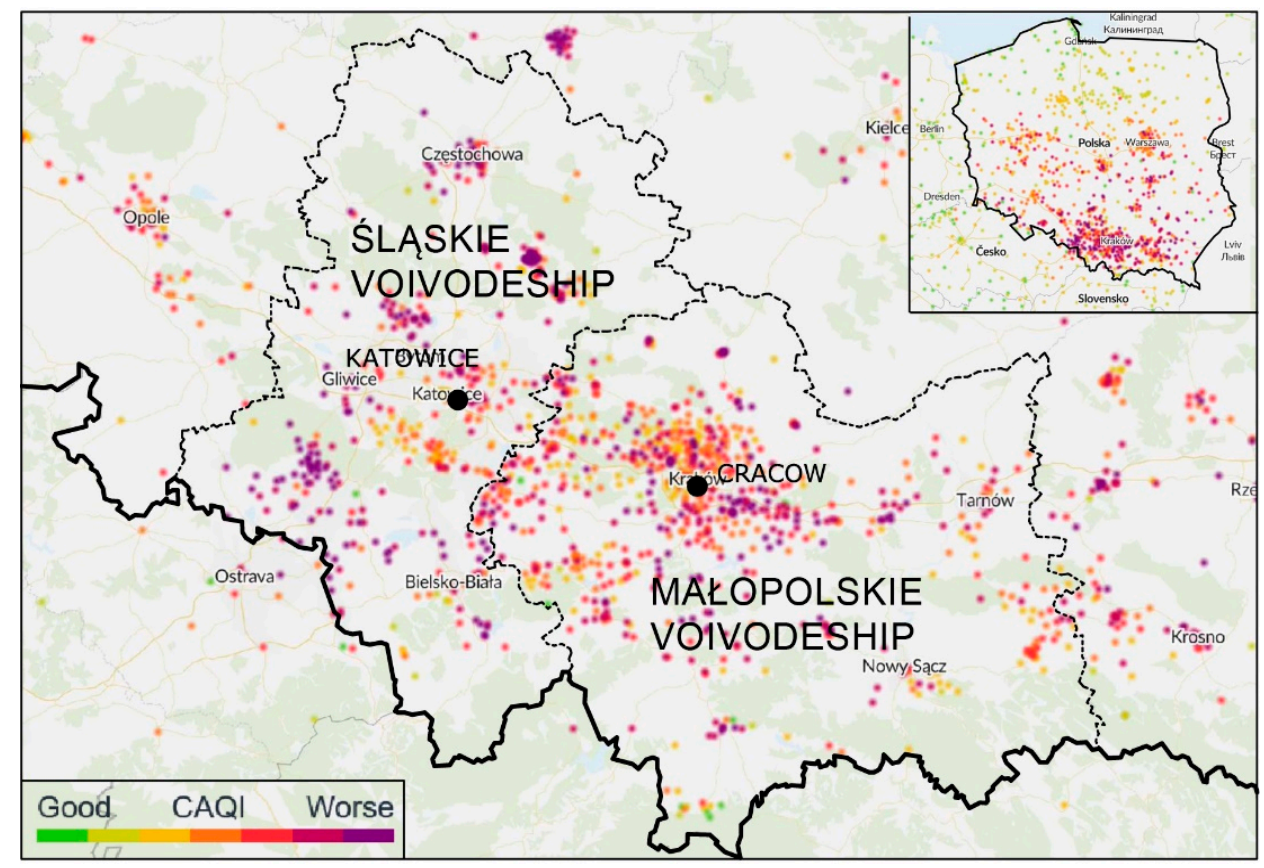

Figure 1. Air pollution in the Małopolskie and Śląskie voivodeships. Airly app measurement [31]. Data on 31 January 2021, at 10 PM. 
Hence, it is rational to conduct research in these voivodeships, where the air pollution concentration is the highest. This region is also important because of its border location. Such a location causes the pollutant emission to travel outside Poland-to Czech Republic and Slovakia [15,32]. Both countries have been monitoring cross-border emissions since 2017, assessing how much pollution comes from Poland [33]. Thus, two voivodeships were included in the research area: with the largest surface areas and the largest number of heavily polluted localities.

\section{Air Pollution-Situation in the Area of Śląskie and Małopolskie Voivodeships}

According to the State of the Environment Report in the Małopolskie voivodeship in 2017, the air quality in the Krakow Agglomeration does not meet the criteria specified for particulate matter PM10 and PM2.5, the content of benzo(a)pyrene in particulate matter PM10, and also for nitrogen dioxide. Surface emissions related to individual heating of buildings in the municipal and housing sector and, secondly, transport emissions, are the main reasons for the exceedances in the region. In the case of Krakow, these figures correspond to $39 \%$ and $16 \%$ of the total emissions, respectively. Thirty-nine percent of the share (for PM10 particulate matter) in air pollution in Krakow is the inflow from neighboring communes. With reference to the voivodeship, the inflow from neighboring zones is significant-especially from the Slaskie voivodeship. In this context, the topography and meteorological conditions have a decisive influence on the specific local spreading conditions and the accumulation of pollutants [34,35]. In the last 2 years, a slight improvement in air quality has been observed, especially in terms of the level of PM10 particulate matter in the voivodeship and nitrogen dioxide in the Krakow Agglomeration [36].

According to the State of the Environment Report in the Ślaskie voivodeship in 2017 , in spite of carrying out many activities to improve air quality, the most important problem is, in the winter season, excessive concentrations of particulate matter PM10 and PM2.5 and benzo(a)pyrene, and in the summer season, high concentrations of tropospheric ozone. Exceeding the permissible daily concentration of PM10 particulate matter covers the area of the entire Ślaskie voivodeship. This situation occurs mainly in the winter and it is the effect of particulate matter emission from the individual heating of buildings. The annual standards for PM10 and PM2.5 were exceeded in a smaller area with high population density. In the case of PM2.5 particulate matter, the percentage of the population exposed to above-average concentrations in 2018 was $95 \%$ [37,38]. A positive phenomenon, observed since 2011, is the reduction of the average annual concentrations of sulfur dioxide, amounting to approximately 30\% [39]. Still, the scale of exceedances of air quality standards in the Slaskie voivodeship is one of the highest in Poland [40].

Solid fuel boilers and stoves dominate the structure of heating sources for single-family houses in the Małopolskie and Ślaskie voivodeships. In the case of 77\% of single-family houses in the Małopolskie voivodeship and 81\% in the Slaskie voivodeship, the main source of heating is a coal-fired boiler or stove. In accordance with the regional anti-smog resolutions adopted in 2017 in Małopolskie, coal or wood-fired boilers that do not meet any emission standards should be replaced by the end of 2022, and class 3 and 4 boilers by 2026 . In the Slaskie voivodeship, those boilers that do not meet the emission standards may be used until the end of 2025 [41].

\section{Scenario Analysis-Assumptions}

The amount of emission reductions depends on the number of buildings undergoing thermal modernization. On the other hand, the number of people willing to carry out thermal modernization is related to the level of its external financial support. Four scenarios have been developed to identify possible environmental effects in the context of the amount of funding.

The assumptions of the scenario analysis, concerning the relationship between the amount of the grant and the number of owners of single-family houses willing to insulate 
external partitions, were based on the results of studies conducted by M. Dzikuć and others [21]. On their basis, similar assumptions were made:

1. In the first scenario, a $100 \%$ subsidy from the state budget was adopted-which is allowed under the "Clean Air" Program. In this scenario, the authors of the article accepted a 100\% share of people applying for the building thermal modernization program.

2. The second scenario involves $80 \%$ state budget funding. In this variant, the involvement of building owners was set at the level of $75 \%$ of all respondents.

3. In the third scenario, the proposed grant is $60 \%$ of the cost, and the number of participants in the thermal modernization program has been set at $40 \%$.

4. In the fourth and final scenario, the grant amount was set at $40 \%$. In this case, the projected number of participants in the thermal modernization program decreases to $25 \%$ of the total concerned.

For each scenario, the cost of thermal modernization was estimated by voivodeship. The following assumptions were made to obtain the pollution indicators relevant for the estimation of the ecological effect:

(a) Emission depends on: the type of fuel, fuel consumption, and efficiency of the reduction device [42] (if present in the technological system). The result is the difference between emissions before and after the modernization of the energy (emissions) source. The following formula shall be used to calculate the magnitude of the effect of (reducing or avoiding) carbon monoxide (CO) and $\mathrm{NOx}$ and $\mathrm{SO}_{2}$ emissions [43]:

$$
\mathrm{E}=\mathrm{B} \times \mathrm{W}
$$

where:

$\mathrm{E}=$ emissions of the substance, expressed in kilograms [kg],

$\mathrm{B}$ = fuel consumption: for solid fuels expressed in megagrams/year $[\mathrm{Mg} / \mathrm{year}]$, in the case of gaseous fuels expressed in millions of cubic metres/year [million. $\mathrm{m}^{3} /$ year], liquid fuels expressed in cubic metres/year $\left[\mathrm{m}^{3} /\right.$ year $]$,

$\mathrm{W}=$ the emission factor expressed in kilograms per unit of fuel consumed;

where an emission reduction device is installed behind the combustion source (boiler), its size shall be determined according to:

$$
\mathrm{E}^{\prime}=\mathrm{E} \times(100-\mathrm{ç}) / 100
$$

where:

$\mathrm{E}^{\prime}=$ emission of the substance after correction due to reduction in the installed device, expressed in kilograms [kg],

$\mathrm{E}=$ emission before the reduction device, expressed in kilograms $[\mathrm{kg}]$,

$\eta=$ efficiency of the reduction device expressed as a percentage [\%];

(b) The following formula shall be used to calculate the magnitude of the effect of (reducing or avoiding) particulate matter emissions:

$$
\mathrm{E}^{\prime \prime}=\mathrm{E} \times(100-\eta) /(100-\mathrm{k})
$$

where:

$\mathrm{E}^{\prime \prime}=$ emission of the substance after correction due to the reduction in the installed device, expressed in kilograms $[\mathrm{kg}]$,

$\eta=$ efficiency of the reduction device expressed as a percentage [\%],

$\mathrm{k}=$ content of combustible parts in particulate matter [\%],

$\mathrm{E}=$ emission before the reduction device, expressed in kilograms $[\mathrm{kg}]$

$$
\mathrm{E}=\mathrm{B} \times \mathrm{W}
$$


where:

$\mathrm{E}=$ emission of the substance, expressed in kilograms $[\mathrm{kg}]$,

$\mathrm{B}=$ fuel consumption: for solid fuels expressed in megagrams/year $[\mathrm{Mg} /$ year $]$, in the case of gaseous fuels expressed in millions of cubic metres/year [million. $\mathrm{m}^{3} /$ year], liquid fuels expressed in cubic metres/year $\left[\mathrm{m}^{3} /\right.$ year $]$,

$\mathrm{W}=$ the emission factor expressed in kilograms per unit of fuel consumed.

Analyses of the level of air pollution generated were carried out for two types of singlefamily buildings: uninsulated (before thermal modernization) with an annual demand for renewable primary energy EP of about $180 \mathrm{kWh} /\left(\mathrm{m}^{2}\right.$ year), and a well-insulated building (after insulating of external walls) with an EP of about $90 \mathrm{kWh} /\left(\mathrm{m}^{2}\right.$ year) - both using solid fuel boilers [44,45].

The comparison allowed us to obtain data that illustrate how the different investment scenarios improve air quality, in particular reducing PM2.5 and PM10 dust pollution. These data make it possible to identify and adapt individual investment scenarios to the scale of the risks and needs of the area resulting from air quality.

\section{Scenario Analysis of Thermal Modernization in the Małopolskie and Śląskie Voivodeships}

\subsection{Data Sources}

In Małopolskie and Ślaskie there are more than one million single-family buildings [46]. The area of research is characterized by a large number of dispersed, detached housing $[47,48]$. Its spatial structure and topographical, environmental, and transport conditions $[49,50]$ also promote the tendency to form compact settlement clusters. Very often, clusters of buildings occur in mountain valleys [51,52], as well as along transport corridors [53]. In particular, cities and towns with historical urban layouts have a compact development [54].

The number of single-family buildings located in the Śląskie and Małopolskie voivodeships is comparable. Differentiation occurs in relation to the number of non-insulated objects. On the basis of data from the National Population and Housing Census from 2011 and [55] and the average annual increases in the number of newly constructed buildings, it was assumed that at the end of 2016 there were 563,700 single-family houses in the Małopolskie voivodeship, of which 190,500 were non-insulated There were 547,200 of them in the Ślaskie voivodeship, including a non-insulated 293,200 (Table 1).

Table 1. List of the number of single-family houses in the Małopolskie and Ślaskie Voivodeships [46].

\begin{tabular}{ccc}
\hline Voivodeship & Małopolskie & Śląskie \\
\hline Number of non-insulated buildings & 190,500 & 293,200 \\
Number of insulated buildings & 373,200 & 254,000 \\
Number of buildings using solid fuel stoves (insulated and & 435,000 & 470,000 \\
non-insulated) & 563,700 & 547,200 \\
\hline
\end{tabular}

The number of single-family buildings that could be thermomodernized in the Małopolskie and Ślaskie voivodeships was estimated on the basis of the results of survey research among owners of single-family houses in Poland, carried out in 2017 by the CEM Market and Public Opinion Research Institute on behalf of the Institute of Environmental Economics (Table 2). 
Table 2. Renovation needs in Poland-survey results [56].

\begin{tabular}{cc}
\hline Type of Renovation Investments & Renovation Needs-Preferences \\
\hline Modernization of the heating system, & $34.1 \%$ \\
including boiler replacement & $26.5 \%$ \\
Roof renovation with insulation & $26.0 \%$ \\
Insulation of building walls & \\
\hline
\end{tabular}

According to surveys, most people indicated the need to modernize the heating system with the replacement of the boiler. The need to renovate the roof with its insulation was declared by $26.5 \%$ of those surveyed, and the insulation of the walls of the building, $26.0 \%$. For this reason, for the purposes of this article, a coefficient of the number of buildings that can be thermomodernized at $26.0 \%$ has been adopted and applied to the Małopolskie and Ślaskie voivodeships. On this basis, it was estimated that the number of such buildings in Małopolskie is 146,562 and in Ślaskie 142,272 (Table 3). It was assumed that these figures will be realized in the case of $100 \%$ of the funding for thermal modernization activities.

Table 3. Number of single-family buildings planned for thermal modernization in the Małopolskie and Śląskie Voivodeships.

\begin{tabular}{ccc}
\hline Voivodeship & $\begin{array}{c}\text { Number of Single-Family } \\
\text { Buildings }\end{array}$ & $\begin{array}{c}\text { Number of Potential Buildings Subject to } \\
\text { Thermal Modernization }\end{array}$ \\
\hline Małopolskie & 563,700 & 146,562 \\
Śląskie & 547,200 & 142,272 \\
In total & $1,110,900$ & 288,834 \\
\hline
\end{tabular}

The number adopted is relatively small in the case of the Ślaskie voivodeship in relation to the number of non-insulated buildings. It accounts for almost half of them- $48.52 \%$. In the Małopolskie voivodeship, this share is $76.93 \%$ due to the large number of objects already insulated.

\subsection{Financial Costs and Ecological Effects}

To determine the cost intensity of thermal modernization of a single-family building in the Małopolskie and Ślaskie voivodeships, it was concluded that an average cost of thermal insulation of one single-family house with floor space of $120 \mathrm{~m}^{2}$ amounts to EUR 16,000 [56]. The amount was based on an analysis of market prices and averaged construction portal prices [57] used for the cost of construction works. It includes thermal insulation of exterior walls and roof. The adopted average usable floor area allows us to reflect the current situation in the structure of single-family houses that require thermal insulating. The largest proportion of such buildings is construction objects built before the First World War and between 1945 and 1988. From 1957 to the 1970s, Poland had urban standards for low-level housing, which set the maximum floor area of a residential unit in single-family houses at $110 \mathrm{~m}^{2}$ (with admission of $140 \mathrm{~m}^{2}$ if the professional work of the building owner was allowed) [58]. The average area adopted in the research also includes subsequent implementations.

Similarly to the study carried out for the Lubuskie voivodeship, where four scenarios were considered, the level of the number of participants was assumed to depend on the degree of co-financing of building thermal modernization.

The Śląskie voivodeship has specific functional, spatial, and topographic conditions. A large share of single-family housing areas results in significant areas with high air pollution emissions [59]. The topographical conditions of the region also cause poor air exchange in some areas due to the presence of mountain areas and valleys and basins (e.g., the Żywiec Basin) in the southern part of the voivodeship. It is worth noting here that despite the fact that the Slaskie voivodeship $\left(12,333 \mathrm{~km}^{2}\right)$ is smaller in area than the Małopolskie 
voivodeship $\left(15,183 \mathrm{~km}^{2}\right)$, the number of single-family buildings that do not have thermal insulation is higher and amounts to 293,200 in comparison to 190,500 in Małopolskie.

Tables 4 and 5 present scenarios for both voivodeships. The tables show how the costs of subsidies are distributed. In scenario 1, with $100 \%$ co-financing, the amount of over EUR 2 billion was obtained in both voivodeships, with the number of buildings covered by the program being 146,562 (Małopolskie) and 142,272 (Ślaskie). On the other hand, in the fourth scenario, with the financing at the level of $40 \%$, the costs of the program amounted to over EUR 200 million for both voivodeships. Scenario 4 makes it possible to cover 36,640 buildings in Małopolskie and 35,568 buildings in Śląskie.

Table 4. List of scenarios in the Małopolskie Voivodeship. Number of buildings included: 146,562.

\begin{tabular}{cccc}
\hline $\begin{array}{c}\text { Scenario and \% of } \\
\text { Support }\end{array}$ & $\begin{array}{c}\text { Co-Financing Amount for } \\
\text { Thermal Modernization (EUR) }\end{array}$ & $\begin{array}{c}\text { Number of Buildings } \\
\text { Covered by the Program }\end{array}$ & $\begin{array}{c}\text { Potential Cost of Modernization } \\
\text { of Buildings in Millions of Euros }\end{array}$ \\
\hline First 100\% & 16,000 & 146,562 & 2344.9 \\
Second 80\% & 12,800 & 109,921 & 1406.9 \\
Third 60\% & 9600 & 58,625 & 562.8 \\
Fourth 40\% & 6400 & 36,640 & 234.5 \\
\hline
\end{tabular}

Table 5. List of scenarios in the Ślaskie Voivodeship. Number of buildings included: 142,272.

\begin{tabular}{cccc}
\hline $\begin{array}{c}\text { Scenario and \% of } \\
\text { Support }\end{array}$ & $\begin{array}{c}\text { Co-Financing Amount for } \\
\text { Thermal Modernization (EUR) }\end{array}$ & $\begin{array}{c}\text { Number of Buildings } \\
\text { Covered by the Program }\end{array}$ & $\begin{array}{c}\text { Potential Cost of Modernization } \\
\text { of Buildings in Millions of Euros }\end{array}$ \\
\hline First 100\% & 16,000 & 142,272 & 2276.3 \\
Second 80\% & 12,800 & 106,704 & 1365.8 \\
Third 60\% & 9600 & 56,909 & 546.3 \\
Fourth 40\% & 6400 & 35,568 & 227.6 \\
\hline
\end{tabular}

Combustion of fuels, in particular solid fuels, causes emission of pollutants hazardous to human health. Not only the type of fuel, but also the design of the boiler, the burner, and the setting of its operating parameters are important in this respect. The basic products of combustion are carbon dioxide $\left(\mathrm{CO}_{2}\right)$, water vapour $\left(\mathrm{H}_{2} \mathrm{O}\right)$, and nitrogen oxide (NOx). Depending on the type of fuel and the combustion process, the following can also be emitted: sulphur compounds $\left(\mathrm{SO}_{2}\right)$, carbon monoxide $(\mathrm{CO})$, and dust. Based on the above data, scenarios were developed for the Małopolskie and Śląskie voivodeships. The data thus generated have been presented together with data on emissions from single-family buildings, depending on the source of heating and the quality of thermal insulation of the building.

Based on the calculations, tables have been prepared for the emission of pollutants resulting from heating homes with solid fuels. The following assumptions have been made for the purpose of the study: average area of a single-family building $-120 \mathrm{~m}^{2}$; average number of people living in the building-3 people; average water consumption per person in the building according to the standard of needs [60,61]; the average temperature of hot water in the circulation of the water supply system of the building - 45 degrees Celsius; and the number of days of hot water use in the building-365. For the purpose of the calculations, the lack of internal circulation of hot water was also assumed. In the first place, the emissions of pollutants generated by a non-insulated single-family building ( $\mathrm{EP}=180$ $\mathrm{kWh} /\left(\mathrm{m}^{2}\right.$ year)) heated with solid fuel were calculated. (In this case, two types of solid fuel boilers were used: a culm boiler and an eco-pea coal boiler.) As a result of analyses, air pollution parameters were obtained, presented in Table 6. Particularly important here were emissions of particulate matter including benzo(a)pyrene. 
Table 6. Summary of the annual emission of pollutants for a non-insulated building (EP $=180$ $\mathrm{kWh} /\left(\mathrm{m}^{2}\right.$ year $\left.)\right)$.

\begin{tabular}{cccccc}
\hline Solid Fuel (Coal) & $\begin{array}{c}\mathrm{CO}_{2} \\
(\mathbf{k g} / \text { Year) }\end{array}$ & $\begin{array}{c}\mathrm{CO} \\
(\mathbf{k g} / \text { Year) }\end{array}$ & $\begin{array}{c}\text { Particulate Matter } \\
\text { (kg/Year) }\end{array}$ & $\begin{array}{c}\mathrm{SO}_{2} \\
\text { (kg/Year) }\end{array}$ & $\begin{array}{c}\text { NOx } \\
\text { (kg/Year) }\end{array}$ \\
\hline Boiler for culm & 17,529 & 721.8 & 18.11 & 98.99 & 14.44 \\
Boiler for eco-pea coal & 14,469 & 595.8 & 15.95 & 81.71 & 11.92 \\
\hline
\end{tabular}

To obtain comparable data for a well-insulated building $\left(\mathrm{EP}=90 \mathrm{kWh} /\left(\mathrm{m}^{2}\right.\right.$ year $)$, an analogous calculation system was used. The results are presented in Table 7. The same heating source was assumed-culm and eco-pea coal. The results of calculations indicate that with the use of this type of power supply there was a significant reduction in particulate matter and sulphur dioxide. $\mathrm{CO}_{2}$ emissions were also significantly reduced.

Table 7. Summary of the annual emission of pollutants for a well-insulated building (EP = $90 \mathrm{kWh} /\left(\mathrm{m}^{2}\right.$ year $)$ - -after thermal modernization.

\begin{tabular}{cccccc}
\hline Solid Fuel (Coal) & $\begin{array}{c}\mathrm{CO}_{2} \\
\text { (kg/Year) }\end{array}$ & $\begin{array}{c}\mathrm{CO} \\
\text { (kg/Year) }\end{array}$ & $\begin{array}{c}\text { Particulate Matter } \\
\text { (kg/Year) }\end{array}$ & $\begin{array}{c}\mathrm{SO}_{2} \\
\text { (kg/Year) }\end{array}$ & $\begin{array}{c}\text { NOx } \\
\text { (kg/Year) }\end{array}$ \\
\hline Boiler for culm & 9878 & 406.80 & 10.20 & 55.79 & 8.14 \\
Boiler for eco-pea coal & 8349 & 343.80 & 8.62 & 47.15 & 6.88 \\
\hline
\end{tabular}

Then, the changes in the emission of pollutants that can be obtained as a result of thermal modernization of the single-family buildings under consideration in the region were calculated. The results have been compared with particular scenarios for both voivodeships (Tables 8 and 9) The above data illustrate the reduction of annual emissions for single-family houses after thermal insulation. The figures have been divided into individual scenarios and show the share of the grant amount in comparison with the environmental effect. The values represent the quantitative reduction of specific pollutants in air emissions. The breakdown includes the type of solid fuel burned. In particular scenarios, the number of buildings participating in the thermal modernization program has also been taken into account, depending on the adopted scenario.

Table 8. Summary data related to the reduction in annual emissions of pollutants after thermal modernization of singlefamily buildings according to scenarios in the Małopolskie Voivodeship.

\begin{tabular}{|c|c|c|c|c|c|c|c|c|}
\hline \multirow[t]{2}{*}{ Scenario } & \multirow[t]{2}{*}{$\begin{array}{l}\text { Number of } \\
\text { Buildings }\end{array}$} & \multirow[t]{2}{*}{$\begin{array}{l}\text { Subsidy (in } \\
\text { Millions Euro) }\end{array}$} & \multirow[t]{2}{*}{$\begin{array}{l}\text { Solid Fuel } \\
\text { Boiler }\end{array}$} & \multicolumn{5}{|c|}{ Reduction of Emissions } \\
\hline & & & & $\begin{array}{l}\mathrm{CO}_{2} / \mathrm{kT} \\
\text { Per Year }\end{array}$ & $\begin{array}{l}\text { CO/kT } \\
\text { Per Year }\end{array}$ & $\begin{array}{c}\text { Particulate Matter/kT } \\
\text { Per Year }\end{array}$ & $\begin{array}{l}\mathrm{SO}_{2} / \mathrm{kT} \\
\text { Per Year }\end{array}$ & $\begin{array}{l}\text { NOx/kT } \\
\text { Per Year }\end{array}$ \\
\hline \multirow{2}{*}{1} & \multirow{2}{*}{146,562} & \multirow{2}{*}{2344.9} & Culm & 1121.3 & 46.2 & 1.16 & 6.4 & 1.0 \\
\hline & & & Eco-pea coal & 897.0 & 37.0 & 0.93 & 5.0 & 0.7 \\
\hline \multirow{2}{*}{2} & \multirow{2}{*}{109,921} & \multirow{2}{*}{1406.9} & Culm & 841.0 & 34.7 & 0.87 & 4.8 & 0.7 \\
\hline & & & Eco-pea coal & 672.7 & 27.8 & 0.70 & 3.9 & 0.6 \\
\hline \multirow{2}{*}{3} & \multirow{2}{*}{58,625} & \multirow{2}{*}{562.8} & Culm & 448.5 & 18.5 & 0.46 & 2.6 & 0.35 \\
\hline & & & Eco-pea coal & 358.7 & 14.8 & 0.37 & 2.2 & 0.29 \\
\hline \multirow{2}{*}{4} & \multirow{2}{*}{36,640} & \multirow{2}{*}{234.5} & Culm & 280.3 & 11.5 & 0.29 & 1.6 & 0.24 \\
\hline & & & Eco-pea coal & 224.2 & 9.3 & 0.23 & 1.3 & 0.23 \\
\hline
\end{tabular}


Table 9. Summary data related to annual emissions of pollutants after thermal modernization of single-family buildings according to scenarios in the Ślaskie Voivodeship.

\begin{tabular}{|c|c|c|c|c|c|c|c|c|}
\hline Scenario & $\begin{array}{l}\text { Number of } \\
\text { Buildings }\end{array}$ & $\begin{array}{l}\text { Subsidy (in } \\
\text { Millions Euro) }\end{array}$ & $\begin{array}{l}\text { Solid Fuel } \\
\text { Boiler }\end{array}$ & & & Reduction of Emissions & & \\
\hline & & & & $\begin{array}{l}\mathrm{CO}_{2} / \mathrm{kT} \\
\text { Per Year }\end{array}$ & $\begin{array}{l}\text { CO/kT } \\
\text { Per Year }\end{array}$ & $\begin{array}{c}\text { Particulate Matter/kT } \\
\text { Per Year }\end{array}$ & $\begin{array}{l}\mathrm{SO}_{2} / \mathrm{kT} \\
\text { Per Year }\end{array}$ & $\begin{array}{l}\text { NOx/kT } \\
\text { Per Year }\end{array}$ \\
\hline \multirow{2}{*}{1} & \multirow{2}{*}{142,272} & \multirow{2}{*}{2276.3} & Culm & 1088.3 & 44.9 & 1.13 & 6.2 & 1.0 \\
\hline & & & Eco-pea coal & 870.7 & 35.9 & 0.90 & 4.9 & 0.8 \\
\hline \multirow{2}{*}{2} & \multirow{2}{*}{106,704} & \multirow{2}{*}{1365.8} & Culm & 816.4 & 33.6 & 0.84 & 4.7 & 0.6 \\
\hline & & & Eco-pea coal & 653.0 & 28.9 & 0.68 & 3.7 & 0.6 \\
\hline \multirow{2}{*}{3} & \multirow{2}{*}{56,909} & \multirow{2}{*}{546.3} & Culm & 435.3 & 17.9 & 0.45 & 2.4 & 0.32 \\
\hline & & & Eco-pea coal & 348.3 & 14.3 & 0.36 & 1.9 & 0.27 \\
\hline \multirow{2}{*}{4} & \multirow{2}{*}{35,568} & \multirow{2}{*}{227.6} & Culm & 272.1 & 11.1 & 0.28 & 1.6 & 0.21 \\
\hline & & & Eco-pea coal & 217.7 & 8.9 & 0.23 & 1.3 & 0.22 \\
\hline
\end{tabular}

Figures 2 and 3 illustrate the change in the level of particulate matter air pollution depending on the adopted variant of thermal upgrading for buildings using solid fuels for heating, such as eco-pea coal and fine coal. For the Małopolskie voivodeship, in scenario 1 particulate matter emissions dropped by about $43-44 \%$ compared to baseline data, in scenario 2 by over $32-33 \%$, in scenario 3 by $17-18 \%$, and in scenario 4 by about $11 \%$. Similar indicators were obtained for the Ślaskie voivodeship.

In turn, Figures 4 and 5 illustrate the correlation between the level of co-financing of thermal modernization works and the level of pollution. On their basis it can be seen that scenarios 1 and 2 are the most environmentally efficient, but costs associated with them are very high. Scenario 1 is unlikely because the grant amount in both voivodeships exceeds $16.5 \%$ of the amount foreseen for the "Clean Air" Program for the entire country of Poland. Therefore, scenario 2 appears to be the most favourable in terms of emission reductions of $32-33 \%$ compared to the baseline situation in the context of the funding level. Scenario 3, on the other hand, is more attractive for economic reasons. In this case, however, pollution reductions are only $17-18 \%$, which is almost half the amount achieved in Scenario 2. Scenario 2 is the optimal option, taking into account the emission reduction criterion first.

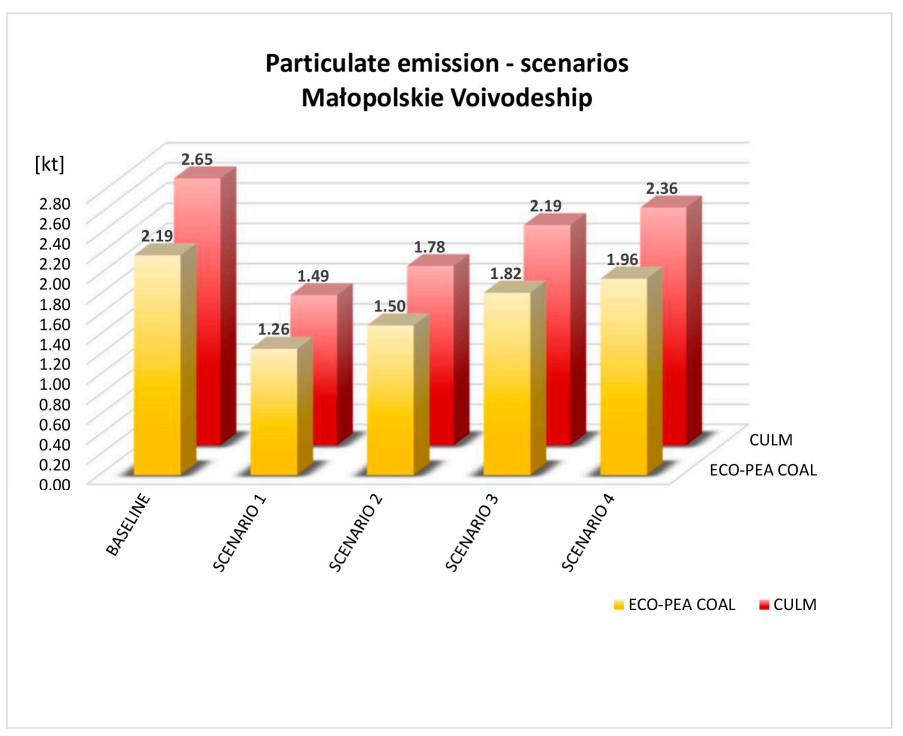

Figure 2. Particulate emission—scenarios for Małopolskie voivodeship. 


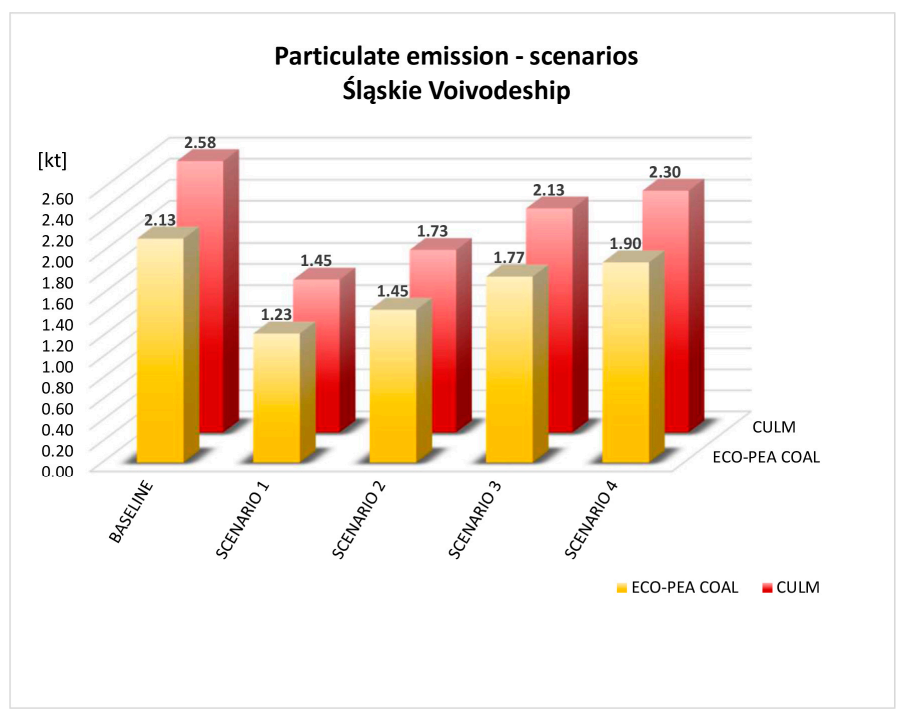

Figure 3. Particulate emission—scenarios for Śląskie voivodeship.

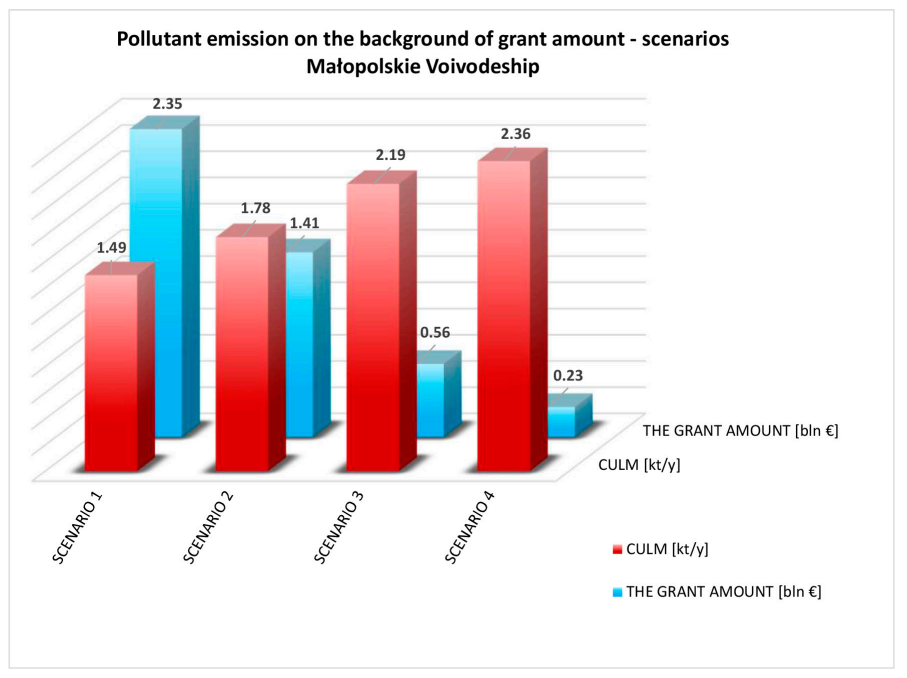

Figure 4. Pollutant emission on the background of grant amount—scenarios for Małopolskie voivodeship.

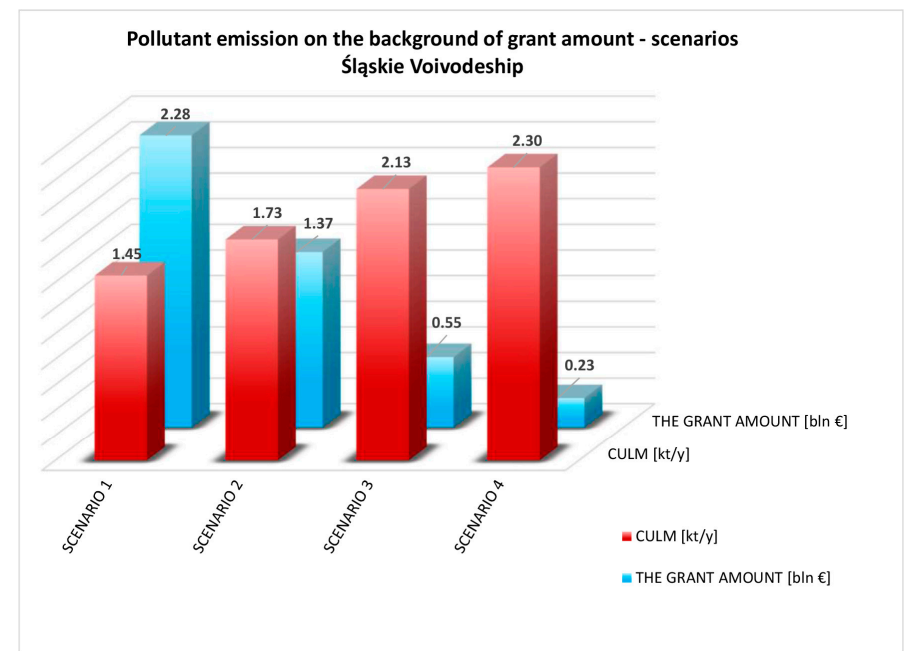

Figure 5. Pollutant emission on the background of grant amount—scenarios for Ślaskie voivodeship. 


\section{Discussion}

The impact of air pollution on the environment is a particularly important issue, inter alia because of the commonness of the phenomenon, the amount of pollutants emitted, the wide range of the impact (from local to global scale), and its negative consequences on human health. Central European countries, including Poland, have a greater need in matters of improvement of air quality. In order to protect the air, it is necessary to ensure synergy of actions under many policies and sectors-both on a local and global scale. In particular, it is important to ensure that air protection measures are consistent with initiatives to combat climate change. Not all climate protection measures lead to improved air quality. The results of research conducted in the Lubuskie voivodeship [21], in which was used a comparable scenario analysis, identified a similar grant option as the optimal. Research carried out in the Małopolskie and Ślaskie voivodeships shows that the optimum environmental effect in relation to the amount of the subsidy is provided by scenario 2. In this case, the grant amount is relatively high at around EUR 1.4 billion. However, it is important to keep in mind the total value of external costs, which come from the current level of pollutant emissions in Małopolskie, up to EUR 1.46 billion per year. These are costs related to inter alia increased mortality, hospital visits, absence from work, and the medical expenses of treating respiratory and cardiovascular diseases. [62] Therefore, it could be considered whether such a form of support (at least $80 \%$ ) should not occur pointwise-in areas particularly threatened by air pollution. In this way, expenses at a regional scale can be reduced while maintaining the highest environmental benefits in the most polluted areas. Both voivodeships are ranked among the most polluted with air pollution in Poland. This results, inter alia, from the population density and spatial structure of single-family housing. In both regions there are particularly polluted areas, where daily concentrations significantly exceed acceptable standards. This is clearly visible in autumn and winter periods [29]. Significant exceedances of the standards make the concentrations in the air dangerous for human health and life [63]. In such areas, it is important to achieve the maximum environmental effect in the shortest possible time. In areas where emissions are lower, the solutions foreseen in scenario 3 might be considered to be implemented. In this variant, expenses are almost three times lower than in scenario 2. Achieving acceptable average daily concentrations of air pollutants should be the main goal of applying particular scenarios. Selection of the scenario should depend on the achieved environmental effects. It is advisable to monitor the adopted scenario and quantitative changes in pollutant emissions. Application of appropriate scenarios may influence the dynamics of thermomodernization processes in a given area.

The adopted research method does not include a comprehensive picture of the emissions of polluters resulting from the heating of single-family buildings in Małopolskie and Ślaskie. Some simplifications have been applied to reduce the number of variables, e.g., the impact of the type of heating source. The focus was solely on the sources generating the most pollutants, i.e., solid fuel boilers. However, these assumptions allowed us to achieve the main objective, which is determining the impact of thermal modernization, which consists solely in insulating the building envelope to reduce emissions of harmful particulate matter. This illustrates the importance of reducing energy demand to heat buildings by insulating them. It underlines the importance of this action in reducing air pollutant emissions.

\section{Conclusions}

In the coming years the implementation of measures for air protection, both in the municipal and household sector, as well as in the power industry, industry and transport, should significantly improve the air quality. Large-scale measures will be of particular importance for the improvement of the quality. Activities related to the introduction of quality standards for solid fuels, the replacement of heating stoves, and the thermal modernization of buildings, as well as the increase in electromobility are conducive to improving air quality. On the basis of the research conducted, it can be concluded that an 
appropriate method of distribution of grants is of particular importance in order to achieve a significant ecological effect. Scenario 2 pays attention, because it shows an optimal level of co-financing in to the context of projected environmental effects-reduction of pollutant emissions, especially particulate matter. It is worth noting that in specific cases, in areas with very high pollutant emissions to the environment, exceeding the national average, it would be advisable to consider scenario 1, assuming $100 \%$ co-financing. It shows the best reduction of pollutant emissions. From the point of view of cost-effectiveness of subsidies in relation to environmental effect, scenario 3 may be an alternative approach in areas with lower pollution emissions. In the context of these studies, analyses of areas predisposed to particular scenarios should be carried out in order to obtain the best reduction coefficient of contaminant emissions into the environment.

Author Contributions: Conceptualization, R.B. and J.B.; methodology, R.P. and J.B.; validation, J.B., R.B. and R.Ł.; formal analysis, R.B. and R.P.; investigation, A.C. and R.Ł.; resources, J.B., A.C., and R.Ł.; data curation, J.B.; writing-original draft preparation, J.B., R.P., R.Ł., and A.C.; writing-review and editing, R.P., J.B., R.Ł., and A.C.; visualization, A.C. and R.Ł.; supervision, R.B.; funding acquisition, R.B. and R.P. All authors have read and agreed to the published version of the manuscript.

Funding: This research received no external funding.

Institutional Review Board Statement: Not applicable.

Data Availability Statement: The datasets used and analyzed during the current study are available from the corresponding author on reasonable request.

Conflicts of Interest: The authors declare no conflict of interest.

\section{References}

1. Blazy, R. Living Environment Quality Determinants, Including $\mathrm{PM}_{2.5}$ and $\mathrm{PM}_{10}$ Dust Pollution in the Context of Spatial IssuesThe Case of Radzionków. Buildings 2020, 10, 58. [CrossRef]

2. European Environment Agency. Poland Country Briefing-The European Environment—State and Outlook 2015. Available online: https: / www.eea.europa.eu/soer/2015/countries/poland (accessed on 24 January 2021).

3. National Air Protection Program until 2020 (with a Perspective Until 2030). Available online: https://www.gov.pl/web/klimat/ krajowy-program-ochrony-powietrza (accessed on 17 February 2021). (In Polish)

4. Czyżewski, B.; Trojanek, R.; Dzikuć, M.; Czyżewski, A. Cost-effectiveness of the common agricultural policy and environmental policy in country districts: Spatial spillovers of pollution, bio-uniformity and green schemes in Poland. Sci. Total Environ. 2020, 726, 138-254. [CrossRef] [PubMed]

5. Woźniak, J.; Pactwa, K. Responsible Mining-The Impact of the Mining Industry in Poland on the Quality of Atmospheric Air. Sustainability 2018, 10, 1184. [CrossRef]

6. Chief Inspectorate of Environmental Protection: State Environmental Monitoring. Available online: https://www.gios.gov.pl/ en/state-of-the-environment/state-environmental-monitoring (accessed on 7 February 2021).

7. Tagaris, E.; Sotiropoulou, R.E.P.; Gounaris, N.; Andronopoulos, S.; Vlachogiannis, D. Effect of the Standard Nomenclature for Air Pollution (SNAP) Categories on Air Quality over Europe. Atmosphere 2015, 6, 1119-1128. [CrossRef]

8. Frankowski, J. Attention: Smog alert! Citizen engagement for clean air and its consequences for fuel poverty in Poland. Energy Build. 2020, 207, 109525. [CrossRef]

9. Program Czyste Powietrze. Clean Air Program. Available online: https://czystepowietrze.gov.pl/ (accessed on 20 January 2021).

10. Dzikuć, M. Problems associated with the low emission limitation in Zielona Góra (Poland): Prospects and challenges. J. Clean. Prod. 2017, 166, 81-87. [CrossRef]

11. Dzikuć, M.; Piwowar, A.; Dzikuć, M.; Kułyk, P.; Easiñski, K. Economic Conditions of Low Emission Reduction in Poland. DEStech Trans. Comput. Sci. Eng. 2018. [CrossRef]

12. Adamczyk, J.; Piwowar, A.; Dzikuc, M. Air protection programmes in Poland in the context of the low emission. Environ. Sci. Pollut. Res. 2017, 24, 16316-16327. [CrossRef]

13. Crisis in the Replacement of Coal Stoves-Report of the Polish Smog Alert. Available online: www.polskialarmsmogowy. pl/polski-alarm-smogowy / aktualnosci/szczegoly,kryzys-w-wymianie-weglowych-piecow--raport-polskiego-alarmusmogowego, 1632.html (accessed on 20 January 2021). (In Polish).

14. Kocova, D.; Kic, P. Technical and economic aspects of thermal insulation of buildings. Engineering for rural development. In Proceedings of the Conference Proceedings, Jelgava, Latvijas Republika, 25-27 May 2016; pp. 50-55.

15. Halkos, G.; Tsilika, K. Understanding transboundary air pollution network: Emissions, depositions and spatio-temporal distribution of pollution in European region. Res. Conserv. Rec. 2019, 145, 113-123. [CrossRef] 
16. Staniūnas, M.; Medineckienè, M.; Zavadskas, E.; Kalibatas, D. To modernize or not: Ecological-economical assessment of multi-dwelling houses modernization. Archiv. Civ. Mech. Eng. 2013, 13, 88-98. [CrossRef]

17. Seibert, R.; Nikolova, I.; Volná, V.; Krejčí, B.; Hladký, D. Air Pollution Sources' Contribution to $\mathrm{PM}_{2,5} \mathrm{Concetration}$ in the Northeastern Part of the Czech Republic. Atmosphere 2020, 11, 522. [CrossRef]

18. Piotrowska-Woroniak, J.; Woroniak. Redukcja emisji zanieczyszczeń w wyniku termomodernizacyji zabytkowych obiektów sakralnych. Reduction of emission pollution as a result of thermomodernisation historic sacral buildings. Civ. Environ. Eng. 2014, 5, 73-77. (In Polish)

19. Oleniacz, R.; Kasietczuk, M.; Rzeszutek, M. Ocena efektów termomodernizacji budynków jednorodzinnych. 1. Zmniejszenie zużycia ciepła i emisji zanieczyszczeń do powietrza. Assessment of the effects of thermal renovation of detached houses. 1. Reduction of hest consumption and pollutant emissions into the air. J. Civ. Eng. Environ. Arch. 2014, 61, 183-196. (In Polish)

20. Lis, A.; Ujma, A. Redukcja emisji pyłów zawieszonych w wyniku poprawy izolacyjności cieplnej przegród i zmiany nośnika energii. Reducing of particulate matter emissions as a result of walls thermal insulation improvement and energy carriers changes. Constr. Optimazed Energy Potential. 2016, 1, 47-54. (In Polish)

21. Dzikuć, M.; Piwowar, A.; Szufa, S.; Adamczyk, J.; Dzikuć, M. Potential and Scenarios of Variants of Thermo-Modernization of Single-Family Houses: An Example of the Lubuskie Voivodeship. Energies 2021, 14, 191. [CrossRef]

22. Gambelli, D.; Vairo, D.; Zanoli, R. Exploiting qualitative information for decision support in scenario analysis. J. Decis. Syst. 2012, 19, 407-422. [CrossRef]

23. Davenport, M.; Delport, M.; Blignaut, N.J.; Hichert, T.; van der Burgh, G. Combining theory and wisdom in pragmatic, scenariobased decision support for sustainable development. J. Environ. Plan. Manag. 2019, 62, 692-716. [CrossRef]

24. Gaspars-Wieloch, H. Critical Analysis of Classical Scenario-based Decision Rules for Pure Strategy Searching. Organ. Manag. Ser. 2020, 149, 155-165.

25. Bondos, I.; Lipowski, M. Podejście scenariuszowe w badaniach marketingowych—Zastosowanie i ograniczenia. Scenario Approach in Marketing Research-Applications and Limitations. Mark. Zarz. 2017, 3, 9-17. (In Polish)

26. Lexa, F.J.; Chan, S. Scenario Analysis and Strategic Planning: Practical Applications for Radiology Practices. JACR 2010, 7, 369-373. [CrossRef]

27. Lowe, P.; Ward, N. England's Rural Futures: A Socio-Geographical Approach to Scenarios Analysis. Reg. Stud. 2009, 43, 1319-1332. [CrossRef]

28. Shalbolt, N.; Apparao, D.; Hunter, S.; Bicknell, K.; Dooley, A. Scenario analysis to determine possible, plausible futures for the New Zealand dairy industry. N. Z. J. Agric. Res. 2017, 60, 349-361. [CrossRef]

29. Polski Alarm Smogowy. The Polish Smog Alert. Available online: https://www.polskialarmsmogowy.pl/ (accessed on 20 January 2021). (In Polish).

30. Chief Inspectorate of Environmental Protection. Assessment of Air Quality in Zones, in Poland in 2019. Available online: https:/ / powietrze.gios.gov.pl/pjp/content/show/1002301 (accessed on 30 January 2021). (In Polish)

31. Airly Air Quality Map. Available online: https:/ / airly.org/map/pl/\#52.4194125211,18.471849959, z6 (accessed on 31 January 2021).

32. Volná, V.; Hladký, D. Detailed Assessment of the Effects of Meteorological Conditions on PM $_{10}$ Concentrations in the Northeastern Part of the Czech Republic. Atmosphere 2020, 11, 497. [CrossRef]

33. Krakovská, A.S.; Svozilík, V.; Zinicovscaia, I.; Vergel, K.; Janèík, P. Analysis of Spatial Data from Moss Biomonitoring in Czech-Polish Border. Atmosphere 2020, 11, 1237. [CrossRef]

34. Podsiadło, K.; Serra, A.O.; Paszyñski, M. Framework for topographic mesh generation and its application to the pollution simulations in Kraków area. Comput. Methods Mater. Sci. 2019, 19, 21-28.

35. Ścibor, M.; Bokwa, A.; Balcerzak, B. Impact of wind speed and apartment ventilation on indoor concentrations of PM10 and PM2. 5 in Kraków, Poland. Air Q. Atmos. Health 2020, 13, 553-562. [CrossRef]

36. Raport o Stanie Środowiska w Województwie Małopolskim w 2017 roku Wojewódzki Inspektorat Ochrony Środowiska w Krakowie. Report on the state of the Environment in the Małopolskie Voivodeship in 2017, Voivodeship Inspectorate for Environmental Protection in Krakow. Available online: http://krakow.pios.gov.pl/stan-srodowiska/publikacje/raporty-ostanie-srodowiska/ (accessed on 23 January 2021). (In Polish)

37. Dziubanek, G.; Spychała, A.; Marchwińska-Wyrwał, E.; Rusin, M.; Hajok, I.; Ćwielag-Drabek, M.; Piekut, A. Long-term exposure to urban air pollution and the relationship with life expectancy in cohort of 3.5 million people in Silesia. Sci. Total Environ. 2017, 580, 1-8. [CrossRef]

38. Kowalska, M.; Skrzypek, M.; Kowalski, M.; Cyrys, J. Effect of $\mathrm{NO}_{x}$ and $\mathrm{NO}_{2}$ Concentration Increase in Ambient Air to Daily Bronchitis and Asthma Exacerbation, Silesian Voivodeship in Poland. Int. J. Environ. Res. Public Health 2020, 17, 754. [CrossRef] [PubMed]

39. Raport o Stanie Środowiska w Województwie Śląskim w 2017. Wojewódzki Inspektorat Ochrony Środowiska w Katowicach. Report on the State of the Environment in the Ślaskie Voivodeship in 2017, Voivodeship Inspectorate for Environmental Protection in Katowice. Available online: http://www.katowice.wios.gov.pl/index.php?tekst=monitoring/raporty/i (accessed on 25 January 2021). (In Polish). 
40. Kobza, J.; Geremek, M.; Dul, L. Characteristics of air quality and sources affecting high levels of $\mathrm{PM}_{10}$ and $\mathrm{PM}_{2.5}$ in Poland, Upper Silesia urban area. Environ. Monit. Assess. 2018, 190, 515. [CrossRef]

41. Energy Efficiency in Poland. 2017 Revieww; Zaborowski, M., Walczak, E., Eds.; Institute of Environmental Economics (IEE): Kraków, Poland, 2018.

42. Kaczmarczyk, M.; Sowiżdżał, A.; Tomaszewska, B. Energetic and Environmental Aspects of Individual Heat Generation for Sustainable Development at a Local Scale-A Case Study from Poland. Energies 2020, 13, 454. [CrossRef]

43. Wojewódzki Fundusz Ochrony Środowiska i Gosodarki Wodnej w Poznaniu. Zestawienie Wzorów i Wskaźników Emisji Substancji Zanieczyszczających Wprowadzanych do Powietrza. Provincial Fund for Environmental Protection and Water Management in Poznañ. Summary of Formulas and Indicators of Emissions of Polluting Substances Discharged into the Air. Available online: www.wfosgw.poznan.pl/wp-content/uploads/2018/01/Definicja-i-wzór-efektu-OA-2018.pdf (accessed on 20 January 2021). (In Polish).

44. Minister of Investment and Development of Republic of Poland. Announcement of the Minister of Investment and Development of 8 April 2019 on the Publication of the Uniform Text of the Ordinance of the Minister of Infrastructure on Technical Conditions to Be Met by Buildings and Their Location; The Prime Minister of Republic of Poland: Warsaw, Poland, 2019; Volume 2019. (In Polish)

45. Kryzia, D.; Pepłowska, M. The impact of measures aimed at reducing low-stack emission in Poland and on energy efficiency and the household emission of pollutants. Polityka Energetyczna 2019, 22, 121-131. [CrossRef]

46. Lewandowski, P.; Sałach, K.; Ziółkowska, K. The Assessment of Labour Demand Generated by Single-Family Buildings Modernisation Projects Implemented in the Voivodships of Małopolskie and Ślaskie. In Energy Efficiency in Poland. 2017 Review; Zaborowski, M., Walczak, E., Eds.; Institute of Environmental Economics (IEE): Kraków, Poland, 2018; pp. 82-86.

47. Blazy, R. Planning Problems and the value of the Urban and Natural Landscape Problems in the Silesian Agglomeration. In IOP Conference Series: Materials Science and Engineering; IOP Publishing: Bristol, UK, 2019; Volume 471, p. 112012.

48. Śleszyński, P.; Gibas, P.; Sudra, P. The Problem of Mismatch between the CORINE Land Cover Data Classification and the Development of Settlement in Poland. Remote Sens. 2020, 12, 2253. [CrossRef]

49. Ciepiela, A.; Łasocha, M. Urban sprawl and spatial planning documents: The case of the municipality of Biecz, Poland. Przestrz. Forma 2020, 44, 231-248.

50. Runge, A.; Runge, J. Polityka lokalna i regionalna w świetle depopulacji- na przykładzie województwa śląskiego. Stud. KPZK 2017, 178, 133-160.

51. Blazy, R.; Hrehorowicz-Gaber, H.; Hrehorowicz-Nowak, A. Green Infrastructure-Countering Ecosystem Fragmentation: Case Study of a Municipality in the Carpathian Foothills. Forests 2021, 12, 78.

52. Węcławowicz-Bilska, E. Wpływ aktywności gospodarczej na kształt przestrzeni małych miast w Karpatach Polskich. The influence of economic activity on the shape of small towns in Polish Carpathians mountains. Space Soc. Econ. 2016, 17, 85-99. (In Polish) [CrossRef]

53. Blazy, R.; Błachut, J.; Ziobro, A. Wpływ Drogowych Korytarzy Transportowych na Przekształcenia Matych i Średnich Miast w Polsce Potudniowej. The Impact of road Transport Corridors on the Transformation of Small and Medium-Sized Cities in Southern Poland; Węcławowicz- Bilska, E., Ed.; Wydaw. PK: Cracow, Poland, 2019. (In Polish)

54. Ciepiela, A.; Kania, O.; Łabuz, R. Małe Miasta o Układach Historycznych w Polsce Południowej. Small Cities and Towns with Historical Urban Layouts in Southern Poland; Wdowiarz-Bilska, M., Ed.; Wydaw. PK: Kraków, Poland, 2019. (In Polish)

55. CSO 2011. National Population and Housing Census 2011 (Narodowy Spis Powszechny Ludności i Mieszkań 2011). Central Statistical Office (CSO). Available online: https: / / stat.gov.pl (accessed on 12 January 2021).

56. Pytliński, Ł. Technical condition of single-family buildings in Poland. Renovation needs, heat sources and energy performance standards. In Energy Efficiency in Poland. 2017 Review; Zaborowski, M., Walczak, E., Eds.; Institute of Environmental Economics (IEE): Kraków, Poland, 2018; pp. 28-68.

57. Ośrodek Wdrożeń Ekonomiczno-Organizacyjnych Budownictwa PROMOCJA Sp. z o.o. Center for Economic and Organizational Implementation of Construction PROMOTION Ltd. Sekocenbud. Available online: https://www.sekocenbud.pl/ aktualnosci/publikacje-ekspertow/sekocenbud-wlasciwy-dla-rynkowej-wyceny-kontraktow-i-opinii-sadowych/ (accessed on 25 January 2021).

58. Zarządzenie Prezesa Komitetu do Spraw Urbanistyki i Architektury z Dnia 28 Sierpnia 1957 r. w Sprawie Normatywu Urbanistycznego dla Niskiego Budownictwa Mieszkaniowego. M.P. 1957 nr 74 poz. 453. Available online: http:/ / isap.sejm.gov.pl/ isap.nsf/DocDetails.xsp?id=WMP19570740453\&SessionID=05A5CF885238D6C5191AC7E60F6ABAD02FE6DEE4 (accessed on 19 March 2021).

59. Bac-Bronowicz, J.; Grzempowski, P. Regionalization of geographical space according to selected topographic factors in reference to spatial distribution of precipitation: Application of artificial neural networks in GIS. Environ. Earth Sci. 2018, 77, 1-17. [CrossRef]

60. Bergel, T.; Kotowski, T.; Woyciechowska, O. Daily water consumption for household purposes and its variability in a rural household. J. Ecol. Eng. 2016, 17, 47-52. [CrossRef]

61. Masłoń, A. Dynamika zmian jednostkowej dobowej ilości ścieków w jednorodzinnym gospodarstwie domowym. Rynek Instal. 2015, 10, 69-73. (In Polish) 
62. Program Ochrony Powietrza dla Województwa Małopolskiego. Air Protection Programme for Małopolskie Vivodeship. Uchwała $\mathrm{Nr}$ XXV/373/20 Sejmiku Województwa Małopolskiego z dnia 28 września 2020 r. w sprawie Programu ochrony powietrza dla województwa małoposkiego. Available online: http:/ / edziennik.malopolska.uw.gov.pl/legalact/2020/6337/ (accessed on 19 March 2021). (In Polish)

63. Analitis, A.; De' Donato, F.; Scortichini, M.; Lanki, T.; Basagana, X.; Ballester, F.; Astrom, C.; Paldy, A.; Pascal, M.; Gasparrini, A.; et al. Synergistic Effects of Ambient Temperature and Air Pollution on Health in Europe: Results from the PHASE Project. Int. J. Environ. Res. Public Health 2018, 15, 1856. [CrossRef] [PubMed] 